\title{
PEMBUATAN MINUMAL HERBAL "TEH SECANG" UNTUK MENINGKATKAN KESEHATAN DAN PEREKONOMIAN MASYARAKAT DESA TANJUNG TAMBAKREJO BOJONEGORO
}

\author{
Ari Abi Aufa \\ Universitas Nahdhatul Ulama` Sunan Giri Bojonegoro \\ Kingari009@gmail.com
}

\begin{abstract}
Abstrak
Covid 19 telah merubah berbagai tatanan dalam kehidupan bermasyarakat. Manusia yang sejatinya merupakan makhluk sosial menjadi terhalang berinteraksi antar sesamanya yang berakibat terhalanginya upaya-upaya pemenuhan kebutuhan dasar hidup manusia. Manusia harus menyesuaikan cara berinteraksi sesama mereka untuk menghindar dari kemungkinan tertular covid 19. Namun di sisi lain manusia tetap harus bekerja untuk memenuhi kebutuhan hidup dirinya dan keluarganya. Masyarakat desa Tanjung Tambakrejo Bojonegoro tidak terlepas dari dampak covid 19.

Pengabdian ini menggunakan metode ABCD yaitu pengabdian yang menitikberatkan pada pemanfaatan aset yang dimiliki oleh daerah tersebut untuk meningkatkan kehidupan mereka. Aset yang ada pada daerah tersebut terkadang terabaikan dan tidak dimanfaatkan secara maksimal oleh penduduk setempat karena ketidaktahuan mereka. Oleh karena itu, metode ini diambil untuk memperkenalkan kembali aset yang ada di tengah-tengah masyarakat agar bisa dimanfaatkan untuk meningkatkan kehidupan mereka.

Berdasar survei yang dilakukan, didapatkan berbagai aset nabati yang belum terrmanfaatkan secara maksimal, salah satunya adalah pohon secang (Caesalpinnia sappan L). Melalui berbagai riset yang dilakukan, ternyata pohon secang dapat diolah menjadi minuman hangat yang nikmat sekaligus menyehatkan. Berdasar hal ini, masyarakat desa Tanjung lalu diajari cara membuat minuman herbal berbahan dasar pohon secang, sekaligus cara pemasaranannya secara online untuk meningkatkan kesehatan sekaligus perekonomian mereka.
\end{abstract}

Kata Kunci: Covid 19, minuman herbal, pohon secang

\begin{abstract}
Covid 19 has changed various orders in social life. Human beings, who are actually social creatures, are prevented from interacting each other, which results in obstructing efforts to fulfill the basic needs of human life. People must adjust the way they interact with each other to avoid the possibility of contracting Covid 19. But on the other hand, people still have to work to make ends meet for themselves and their families. The community of Tanjung Tambakrejo Bojonegoro village cannot be separated from the impact of Covid 19.

This social service uses the ABCD method, which is service that focuses on the use of assets owned by the village to improve their lives. The existing assets in these areas are sometimes neglected and not fully utilized by the local community due to their ignorance. Therefore, this method is taken to reintroduce existing assets in the community so that they can be used to improve their lives.

Based on the survey conducted, it was found that various vegetable assets have not been maximally utilized, one of which is Caesalpinnia sappan L. Through various research conducted, it turns out that Caesalpinnia sappan L can be used as a warm drink that is both
\end{abstract}


delicious and healthy. Based on this, the people of Tanjung village were then taught how to make herbal drink made from Caesalpinnia sappan $L$, and how to sel it online to improve their health and also their economy.

Keywords: Covid 19, herbal drink, Caesalpinnia sappan L

\section{LATAR BELAKANG}

Bangsa Indonesia, bersama dengan berbagai negara di belahan dunia lainnya, merasakan dampak yang cukup besar akibat pandemi Covid 19 yang muncul sejak akhir tahun 2019. Virus yang pertama kali diketahui muncul dan menyebar di negara China tersebut bahkan hingga saat ini belum tampak bisa dimusnahkan meskipun seluruh bangsa telah berjuang dengan segala upaya. Berdasar data yang dirilis Kementerian Kesehatan RI per tanggal 30 Mei 2021, jumlah kasus terkonfirmasi positif Covid 19 di Indonesia menjadi 1.816.041 kasus dengan 1.663.998 sembuh dan 50.404 meninggal. Untuk mengatasi penyebaran kasus tersebut Pemerintah mencanangkan gerakan tiga $\mathrm{M}$, yaitu menggunakan masker, mencuci tangan dengan sabun dan menjaga jarak.

Social distancing yang digalakkan Pemerintah untuk menekan penyebaran virus covid 19 berhadapan dengan kodrat manusia sebagai makhluk sosial yang tidak bisa hidup sendiri tanpa orang lain. Martin heidegger, seorang filsuf Jerman menyatakan "No such thing as a man who exist singly and solely on his own" 1. Apa yang disampaikan Heidegger tersebut menunjukan bahwa secara onto 'logis manusia tidak bisa ada tanpa manusia lain. Dan eksistensi manusia selalu tergantung dengan keberadaan dan interaksinya dengan orang lain.

Selain itu, pemerintah juga menggalakkan WFH (work from home), melarang kerumunan, menutup pasar, melarang sekolah tatap muka dan berbagai tindakan lainnya. Akibat aturan dan pelarangan ini, banyak sendi kehidupan masyarakat yang merasakan dampaknya, salah satunya adalah ekonomi. Masyarakat Indonesia, baik yang diperkotaan maupun di pedesaan, sama-sama merasakan merosotnya pendapatan yang berakibat langsung pada menurunnya daya beli.

Perguruan Tinggi sebagai salah satu pelopor peradaban masyarakat memiliki tanggung yang sama untuk meminimalisir dampak yang ditimbulkan oleh Covid 19 ini. Untuk berperan aktif dalam hal ini, Universistas Nahdlatul Ulama Sunan Giri Bojonegoro melalui Lembaga Penelitian dan Pengabdian Kepada Masyarakat (LPPM) mengirim Tim yang terdiri dari dosen dan dibantu oleh mahasiswa untuk melakukan pengabdian nyata di hampir seluruh Kecamatan di Kabupaten Bojonegoro yang dilaksanakan mulai tanggal 3 Maret 2021 hingga 3 April 2021. Salah satu daerah yang menjadi sasaran kegiatan pengabdian ini adalah desa Tanjung Kecamatan Tambakrejo Kabupaten Bojonegoro.

Desa Tanjung dipilih menjadi lokasi pengabdian karena masyarakat di desa ini turut merasakan dampak langsung dan tidak dari Covid 19 padahal desa ini memiliki potensi alam yang melimpah, terutama kekayaan nabati yang terabaikan dan tidak dimanfaatkan secara maksimal oleh masyarakat. Berdasarkan banyaknya sumber daya alam yang ada di desa Tanjung ini maka pengabdian di desa Tanjung

\footnotetext{
${ }^{1}$ Martin Heidegger, The Question Concerning Technology., Harper and Row, New York, 1977,
} h. 337 
ini mengambil judul " Meningkatkan Ekonomi Desa dengan Memanfaatkan Sumber Daya Alam yang ada di Desa Tanjung".

Secara umum, pandangan tentang pemanfaatan sumber daya alam di seluruh dunia memiliki persamaan, yaitu sumber daya alam sebagai ekosistem integral yang tidak bisa terpisahkan dari seluruh anggota ekosistem tersebut ${ }^{2}$. Meskipun sebagai satu kesatuan ekosistem, namun bentuk dan status penguasaan sumber daya alam tersebut terbagi dalam empat kelompok, yaitu: milik umum (open access), milik negara (state), milik pribadi (private) dan milik bersama (communal) ${ }^{3}$. Hal ini pula yang ada di desa Tanjung. Sebagian sumber daya alam, baik yang berupa tanah maupun tumbuhan yang ada di atasnya, sebagian milik pribadi, sebagian milik desa, dan sebagian milik negara.

Pohon secang merupakan pohon yang tumbuh di pekarangan rumah, sawah maupun hutan yang ada di sekitar desa Tanjung. Masyarakat Tanjung pada umumnya hanya memanfaatkan pohon secang sebagai pagar hidup dan sekaligus pembatas tanah milik. Iklim tropis yang ada di desa Tanjung menjadikan pohon secang dapat tumbuh subur dan dapat melewati berbagai musim.

Masyarakat Tanjung yang umumnya berprofesi sebagai petani tidak terlalu memperhatikan potensi bisnis yang bisa dimunculkan melalui pengolahan pohon secang menjadi minuman herbal. Oleh karena itu, pengabdian yang dilakukan kali ini mengambil tema pemanfaatan pohon secang sebagai penopang kesehatan sekaligus ekonomi masyarakat desa Tanjung Tambakrejo Bojonegoro.

\section{METODE}

Pengabdian kepada masyarakat di desa Tanjung Kecamatan Tambakrejo Kabupaten Bojonegoro ini menggunakan metode ABCD (Asset Based Community Development). Metode ini merupakan metode yang lazim digunakan untuk memanfaatkan potensi yang ada pada suatu daerah yang secara relatif tidak terlalu dimanfaatkan oleh masyarakat. Hal ini bisa terjadi karena beberapa hal, salah satunya karena ketidaktahuan masyarakat terhadap manfaat suatu aset yang ada di desa mereka.

"The ABCD model is a community development method which is based on capacity within community". Melalui metode ini, masyarakat yang menjadi mitra pengabdian dikenalkan dengan potensi yang ada di desa mereka sekaligus diajarkan cara memanfaatkan potensi atau aset tersebut. Setelah masyarakat mengenali aset yang ada di wilayah mereka, diharapkan mereka mampu memanfaatkan aset tersebut sebaik mungkin sehingga bisa meningkatkan taraf kehidupan mereka, baik dari segi ekonomi, kesehatan, sosial dan sebagainya.

2 Hidayat, "Pengelolaan Sumber Daya Alam Berbasis Kelembagaan Lokal", dalam Jurnal Sejarah CITRA LEKHA, Vol. XV, No. 1 Februari 2011: 19-32

${ }^{3}$ Iskandar,J., Manusia, Budaya dan Lingkungan Ekologi, Humaniora Bandung, 2001

4 Nurdiyanah Syarifuddin, Nildawati, Asset-Based Community Development (ABCD):An Approach For Improving Environmental and Behavioral Health, Journal of Computational and Theoretical Nanoscience · January 2017, https://www.researchgate.net/publication/318205175 


\section{Mengenal desa Tanjung Kecamatan Tembakrejo Kabupaten Bojonegoro}

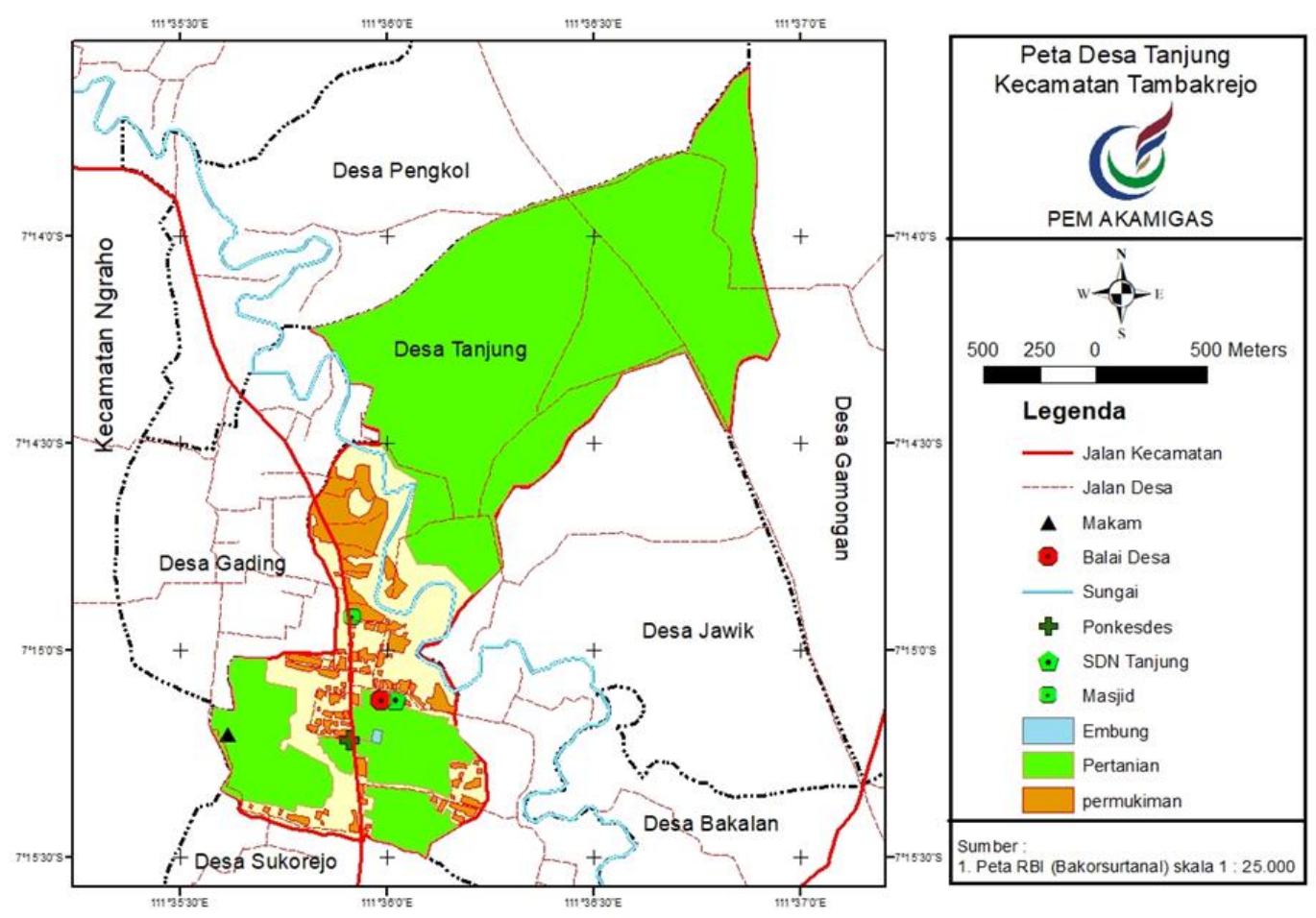

Desa tanjung adalah desa yang terletak di kecamatan Tambakrejo Kabupaten Bojonegoro yang berbatasan antara desa Jawik, Sukorejo, dan Gading. Desa ini memiliki luas $96.000 \mathrm{~m} 2$ yang dihuni oleh 1652 warga yang kesemuanya beragama Islam. Mayoritas warga desa Tanjung hanya berpendidikan sekolah dasar dan berprofesi sebagai petani.

Masyarakat desa Tanjung semua beragama Islam. Banyak kegiatan keagamaan yang dilakukan masyarakat seacar rutin baik mingguan atau bulanan. Di antaranya adalah rutinan yasin dan tahlil ibu-ibu dan bapak-bapak, khotmil qur'an, jamaah manaqib, maulid dhiba', Rotib al-hadad, latihan tari sufi dan sebagainya. Para orang tua di desa Tanjung sangat mendukung saat anak-anaknya ingin melanjutkan pendidikan di pondok pesantren. Hal ini menjadikan kegiatan-kegiatan keagamaan berjalan semakin

Warga desa Tanjung mayoritas bekerja sebagai petani seperti jagung, padi, tebu, dan terong ada juga yang membuat kerajinan dari bambu. Hasil seperti terong dijual di pasar, namun untuk padi mayoritas di timbun di rumah setelah panen. Berdasar hasil wawancara serang warga bernama Mbah Kuri (78) jarang ada yang menjual hasil panen khususnya padi karena mereka beranggapan bahwa menabung padi lebih menguntungkan, kalaupun ingin menjual mereka menjual dalam bentuk beras karena harganya lebih tinggi.

Namun, di sisi lain, sebagian remaja desa Tanjung lebih memilih merantau ke kota-kota besar atau bahkan ke negeri tetangga untuk mendapatkan pekerjaan yang menjanjikan penghasilan lebih besar. Kehidupan sebagai petani yang dianggap tidak terlalu 'menghasilkan' tidak menarik minat sebagian besar remaja di desa ini. Meskipun tidak banyak saingan ataupun ancaman, kehidupan sebagai petani bukanlah profesi yang diharapkan oleh remaja desa ini. Sehingga, dengan merantau, 
menjadi kuli bangunan, asisten rumah tangga, atau jenis pekerjaan lain apapun dianggap lebih menawarkan kehidupan yang lebih baik.

Meskipun banyak potensi alam yang jika diolah dengan baik bisa menghasilkan pendapatan, pada dasarnya remaja atau penduduk desa Tanjung secara keseluruhan tidak terlalu memperhatikan potensi tersebut. Hal ini karakter penduduk desa Tanjung, dan mungkin seluruh masyarakat petani di Indonesia, yang takut mencoba hal baru jika belum ada yang memberi contoh cara melakukannya sekaligus bukti keberhasilannya. Hal ini tentu sangat disayangkan karena begitu melimpahnya potensi alam yang akhirnya tidak dimanfaatkan dengan baik dan optimal.

\section{Survei Lapangan}

Sesuai metode yang digunakan, yaitu Asset Based Community Development, maka langkah pertama yang dilakukan dalam rangka melaksanakan pengabdian ini adalah survei lapangan untuk melihat potensi dan aset yang dimiliki desa Tanjung. Survei dilakukan untuk melihat segala aspek yang ada, baik dari segi sumber daya manusia yang ada maupun sumber daya alam yang dimiliki, termasuk di dalamnya potensi hewani dan nabati.

Survei pertama dilakukan adalah dengan melihat data demografi yang dimiliki pemerintah desa. Berdasar data demografi yang dimiliki pihak desa, didapatkan keterangan sebagai berikut:

1. Kependudukan

a. Jumlah Penduduk:

$\begin{array}{ll}\text { Laki-laki } & : 821 \\ \text { Perempuan } & : 831 \\ \text { Total } & : 1652 \\ \text { Jumlah kepala } & \text { keluarga } 610\end{array}$

b. Agama

Islam : 1652

Kristen : :

Hindu : :

Buddha : :

Konghucu : -

c. Jumlah penduduk menurut mata pencaharian

PNS : 17

TNI/POLLRI $: 8$

Petani : 1175

Dokter/Bidan :-

Lain-lain : 452

2) jenis organisasi yang ada di desa Tanjung

Gerakan Pemuda Ansor

Fatayat

Kelompok Tani Sekar Tanjung

Remaja masjid

IPNU dan IPPNU 
Berdasar data demografi tersebut, tampak tidak terlalu banyak perbedaan jumlah penduduk jika antara laki-laki dan perempuan. Namun jika dilihat dari jenjang pendidikan tampak sekali bahwa rata-rata penduduk desa Tanjung tidak mengenyam pendidikan secara mencukupi dengan mayoritas hanya mengenyam pendidikan di tingkat sekolah dasar. Hal ini berakibat secara tidak langsung pada mata pencaharian mereka. Dengan pendidikan yang cukup rendah, mereka tidak memiliki kesempatan yang cukup untuk berkompetisi atau menciptakan lapangan pekerjaan yang lebih baik. Dengan demikian, sektor pertanian merupakan mata pencaharian yang paling banyak ditekuni oleh warga desa Tanjung yang mungkin mereka dapatkan secara turun temurun.

Selain data demografi, yang tidak kalah penting adalah data tentang potensi alam yang dimiliki desa Tanjung. Dan untuk mendapatkan data ini, dilakukan survei secara langsung melalui eksplorasi ke seluruh wilayah desa Tanjung. Berdasar hasil eksplorasi tersebut banyak didapatkan informasi tentang aset nabati yang dimiliki desa ini, sementara aset hewani tidak terlalu banyak.

Layaknya pedesaan di negeri ini, jumlah persawahan, perkebunan dan tanah lapang lebih luas daripada keseluruhan luas bangunan di desa Tanjung ini. Hal ini berbanding lurus dengan ketersediaan berragam tanaman yang tumbuh dengan subur di desa ini. Berdasar survei yang dilakukan, didapatkan keterangan tentang aset nabati yang cukup melimpah, seperti padi, jagung, terong, singkong, pisang, mangga, jambu, mengkudu, secang, rumput dan sebagainya.

\section{Rasionalisasi}

Setelah didapatkan data demografi maupun potensi alam yang dimiliki, dilakukan rasionalisasi untuk menentukan tindakan selanjutnya. Data demografi menunjukkan bahwa potensi manusia yang bisa diajak dalam kegiatan pemanfaatan sumber daya alam nabati yang terabaikan adalah golongan ibu-ibu dan anak-anak. Hal ini didasarkan pada kenyataan bahwa mereka memiliki lebih banyak waktu luang dibanding kaum lelaki dewasa.

Di antara sumber nabati yang ada, salah satu yang belum termanfaatkan secara maksimal adalah pohon secang. Meskipun pohon secang sudah cukup dikenal sebagai salah satu obat herbal yang bisa menyembuhkan berbagai penyakit, namun pemanfaatannya masih sangat kurang. Hal ini bisa disebabkan masyarakat yang lebih memilih obat-obatan kimia yang lebih cepat memberi efek kesembuhan meskipun dengan resiko munculnya penyakit lain daripada obat herbal yang membutuhkan waktu lama dalam memberi efek kesembuhan meski relatif tidak berresiko memunculkan penyakit lain. Selain itu, masyarakat desa Tanjung juga lebih memanfaatkan pohon secang sebagai pagar pembatas tanah daripada sebagai bahan obat herbal

Mencermati hal ini, maka Tim berupaya menemukan solusi pemanfaatan pohon secang agar bisa dikonsumsi masyarakat secara luas secara praktis dan ekonomis. Lalu disimpulkan untuk membuat pohon secang ini menjadi minuman seduh yang dapat diminum layaknya minum teh yang nikmat dan menyegarkan.

\section{Pohon Secang}

Pohon secang yang dalam istilah latinnya disebut dengan Caesalpinnia sappan $L$ merupakan tanaman tropis yang tumbuh cukup subur di wilayah Indonesia. Tanaman ini meskipun berkambium tidak bisa tumbuh setinggi tanaman-tanaman 
berkambium lainnya, seperti mangga, jambu dan sejenisnya. Karena terlalu subur, pohon ini justru tumbuh tidak terawat dan malah dianggap sebagai tanaman liar.

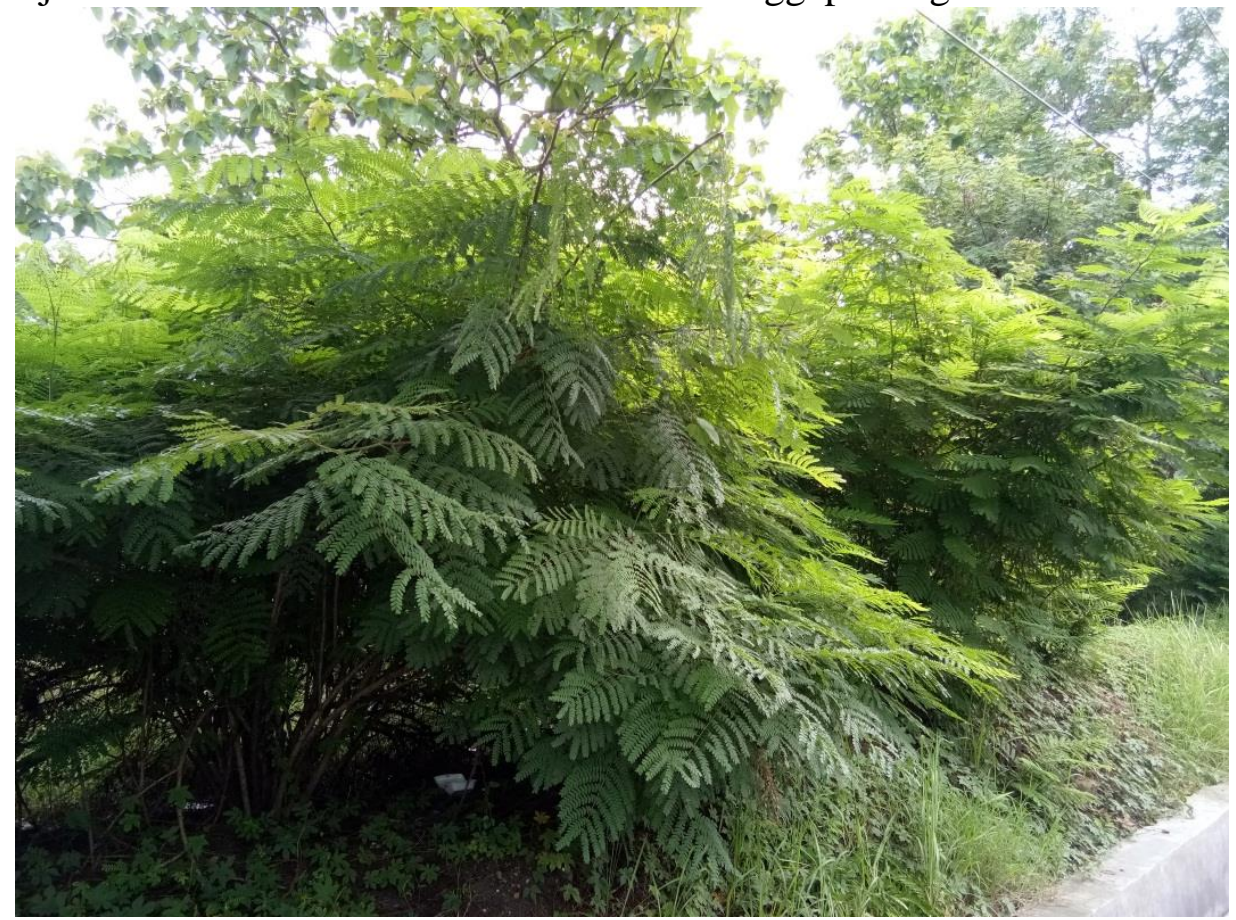

Gambar 1. Pohon secang

Pohon secang secara resmi ditemukan oleh Kimichi (seorang berkebangsaan Spanyol) di daerah Brazil, dan oleh karena itu, pohon secang juga disebut dengan sebutan Brazilian Wood (kayu Brazil). Meskipun demikian, ada yang berpendapat bahwa asal tanaman ini adalah dari India lalu menyebar ke seluruh dunia melalui Burma, Thailand, Indo China sampai Malaysia dan menyebar ke Indonesia, Philipina, Srilangka, Taiwan, dan Hawai. Tanaman ini juga tumbuh subur di seluruh wilayah Eropa, Amerika dan Asia. Secang memiliki nama ilmiah Caesalpinia sappan, dikenal di berbagai negara dengan nama 'sibukao' (Philipina), 'teing nyet' (Burma), 'sbaeng' (Kamboja), 'fang deeng' (Laos), dan 'faang' (Thailand). ${ }^{5}$

Zat kimia yang terkandung dalam pohon secang jika diolah dengan benar dapat memberikan manfaat yang cukup banyak bagi manusia, terutama sebagai obat herbal. Salah satu zat kimia yang terdapat dalam kayu secang adalah brazilien $\left(\mathrm{C}_{16} \mathrm{H}_{14} \mathrm{O}_{5}\right)^{6}$. Zat brazilien ini menghasilkan warna ungu saat direbus dan telah lama dimanfaatkan dalam pembuatan minuman jamu yang dikenal dengan sebutan "bir pletok' yang terkenal di masyarakat Sunda dan Betawi ${ }^{7}$.

\footnotetext{
${ }^{5}$ Ramdana Sari dan Suhartati, "Secang (Caesalpinia sappan L.) : Tumbuhan Herbal Kaya Antioksidan", Info Teknis EBONI Vol. 13 No. 1, Juni 2016 : 57 - 67

6 Holinesti, R. Studi Pemanfaatan Pigmen Brazilein Kayu Secang (Caesalpinia sappan L.) Sebagai Pewarna Alami Serta Stabilitasnya pada Model Pangan. Bogor: Jurnal Pendidikan dan Keluarga UNP, Vol. I, No. 2, Page 11-21. 2009.

${ }^{7}$ Riezky Aulia Yulandani, dkk, "Pengaruh Pemberian Ekstrak Secang (Caesalpinnia Sappan L.) terhadap Kualitas Sensoris dan Mikrobiologis Kue Bolu Kukus Tahun 2014", JURNAL KESEHATAN MASYARAKAT (e-Journal) Volume 3, Nomor 1, Januari 2015 (ISSN: 2356-3346)
} 
Selain mengandung brazilen, kayu secang juga mengandung banyak komponen lain yang dapat diekstrak dan dimanfaatkan untuk kepentingan manusia. Komponen-komponen tersebut antara lain tanin (asam tannat), asam galat, resin, resorsin, dan sappanin. ${ }^{8}$ Dalam dunia medis, tanin dikenal sebagai antibakteri yang sangat bermanfaat bagi manusia. Kadar tanin dari kayu secang dapat diekstrak melalui perebusan. Jika kayu secang direbus selama duapuluh menit, maka dihasilkan zat tanin sebesar $0,137 \% .^{9}$

\section{Pelaksanaan Pelatihan}

Pelaksanaan pelatihan merupakan tujuan utama dalam kegiatan pengabdian ini, karena tujuan utama dari kegiatan pengabdian ini adalah melatih masyarakat untuk memanfaatkan aset yang mereka miliki untuk menciptakan kehidupan yang lebih baik dan bermanfaat. Pelatihan pembuatan minuman herbal berbahan dasar kayu secang ini dilaksanakan di balai desa Tanjung dengan peserta pelatihan dari kalangan ibu-ibu PKK. Pelatihan ini dilaksanakan pada tanggal 18 maret 2021 jam 13:00 - 16:00 WIB.

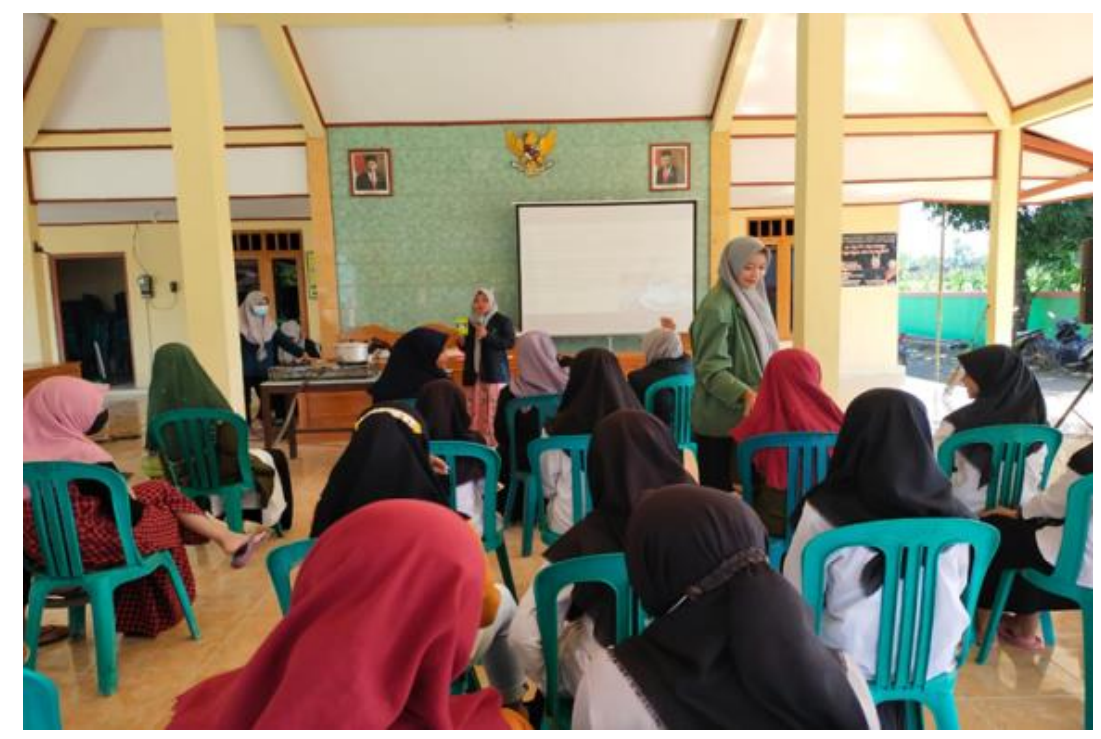

Gambar 2. Peserta pelatihan

Selain melakukan pelatihan pembuatan minuman herbal, peserta pelatihan juga diajari mengemas "wedang secang" agar siap jual dan bisa menarik konsumen. Menggunakan metode penjualan online, pemasaran produk wedang secang diharapkan bisa meningkatkan perekonomian warga desa Tanjung dan

${ }^{8}$ Prasetyo, E \& Kusnadi, J. Formula Bubuk "Teajes" Instan Pada Filtrat Teh Hijau (Camellia sinensis) Dan Filtrat Jahe (Zingiber officinale) Dengan Penambahan Filtrat Kayu Secang (Caesalpinia sappan). Malang: Fakultas Teknologi Pertanian Universitas Brawijaya. 2012. http://tehapeub.net/ejurnal/23ac3-EkoPrasetyo.pdf

${ }^{9}$ Winarti, C. \& B.S. Sembiring. Pengaruh cara dan lama ekstraksi terhadap kadar tannin ekstrak kayu secang (Caesalpinia sappan Linn.). Warta Tumbuhan Obat Indonesia 4(3): 17-18.1998. dalam Winarti, C \& Nurdjanah, N. Peluang Tanaman Rempah Dan Obat Sebagai Sumber Pangan Fungsional. Jurnal Litbang Pertanian, 24(2). 2005. http://pustaka.litbang.deptan.go.id/publi kasi/p3242051. 
sekaligus mensosialisasikan minuman sehat untuk menambah kekebalan tubuh dalam mencgah penyebaran covid 19.

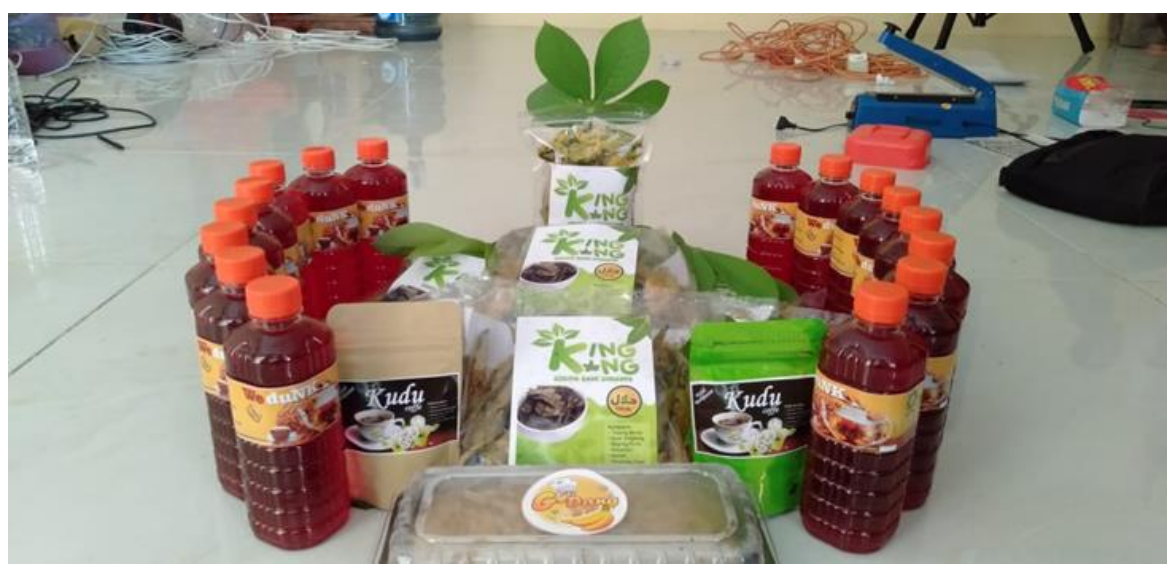

Gambar 3. Wedang secang dalam kemasan botol

\section{KESIMPULAN}

Kegiatan pengabdian yang dilakukan oleh Tim dari UNUGIRI Bojonegoro pada masyarakat desa Tanjung Tambakrejo Bojonegoro pada dasarnya diterima dengan sangat baik oleh masyarakat. Beragam kegiatan yang dilakukan diikuti secara antusias oleh masyarakat sekitar. Hal ini menunjukkan adanya keinginan dari masyarakat setempat untuk mempelajari dan memanfaatkan hal-hal yang sebenarnya tidak baru namun terbaikan oleh mereka.

Kegiatan-kegiatan serupa seharusnya terus dilakukan untuk membantu masyarakat di pedesaan agar ilmu yang didapatkan di bangku perkuliahan dapat dirasakan secara langsung oleh masyarakat luas. Pohon secang bukanlah jenis tanaman yang asing bagi warga masyarakat desa Tanjung, namun terbukti mereka belum tahu cara pemanfaatan yang mudah dan nikmat. Melalui kegiatan pengabdian seperti ini, diharapkan banyak lagi inovasi yang dihasilkan untuk membantu taraf kehidupan masyarakat desa.

\section{DAFTAR PUSTAKA}

Heidegger, Martin,. 1977. The Question Concerning Technology. Harper and Row, New York, ,

Hidayat, Februari 2011. "Pengelolaan Sumber Daya Alam Berbasis Kelembagaan Lokal", dalam Jurnal Sejarah CITRA LEKHA, Vol. XV, No. 1: 19-32

Holinesti, R. 2009. "Studi Pemanfaatan Pigmen Brazilein Kayu Secang (Caesalpinia sappan L.) Sebagai Pewarna Alami Serta Stabilitasnya pada Model Pangan". Bogor: Jurnal Pendidikan dan Keluarga UNP, Vol. I, No. 2, Page 11-21.

Iskandar, J., Manusia, Budaya dan Lingkungan Ekologi, Humaniora Bandung, 2001 Prasetyo, E, Kusnadi, J. 2012. Formula Bubuk "Teajes" Instan Pada Filtrat Teh Hijau (Camellia sinensis) Dan Filtrat Jahe (Zingiber officinale) Dengan Penambahan Filtrat Kayu Secang (Caesalpinia sappan). Malang: Fakultas Teknologi Pertanian Universitas Brawijaya.. http://tehapeub.net/ejurnal/23ac3EkoPrasetyo.pdf

Sari, Ramdana, Suhartati. Juni 2016, "Secang (Caesalpinia sappan L.) : Tumbuhan Herbal Kaya Antioksidan”, Info Teknis EBONI Vol. 13 No. 1,: 57 - 67 
Syarifuddin, Nurdiyanah, Nildawati, January 2017. Asset-Based Community Development (ABCD):An Approach For Improving Environmental and Behavioral Health, Journal of Computational and Theoretical Nanoscience., https://www.researchgate.net/publication/318205175

Winarti, C. \& B.S. Sembiring. 2005. "Pengaruh cara dan lama ekstraksi terhadap kadar tannin ekstrak kayu secang (Caesalpinia sappan Linn.)". Warta Tumbuhan Obat Indonesia 4(3): 17-18.1998. dalam Winarti, C \& Nurdjanah, N. Peluang Tanaman Rempah Dan Obat Sebagai Sumber Pangan Fungsional. Jurnal Litbang Pertanian, 24(2).. http://pustaka.litbang.deptan.go.id/publi kasi/p3242051.

Yulandani, Riezky Aulia, dkk,. Januari 2015. "Pengaruh Pemberian Ekstrak Secang (Caesalpinnia Sappan L.) terhadap Kualitas Sensoris dan Mikrobiologis Kue Bolu Kukus Tahun 2014", JURNAL KESEHATAN MASYARAKAT (e-Journal) Volume 3, Nomor 1, (ISSN: 2356-3346) 